\title{
HVMANITAS
}

\section{[Recensão a] DURÁN LÓPEZ, Ma . Ángeles - Los Dioses en Crisis. Actitud de los Sofistas ante la Tendencia Religiosa del Hombre}
Autor(es):
Rodrigues, Nuno S.

Publicado por: Imprensa da Universidade de Coimbra

URL persistente:

URI:http://hdl.handle.net/10316.2/27392

DOI:

DOI:http://dx.doi.org/10.14195/2183-1718_64_19

Accessed : $\quad$ 26-Apr-2023 06:01:24

A navegação consulta e descarregamento dos títulos inseridos nas Bibliotecas Digitais UC Digitalis, UC Pombalina e UC Impactum, pressupõem a aceitação plena e sem reservas dos Termos e Condições de Uso destas Bibliotecas Digitais, disponíveis em https://digitalis.uc.pt/pt-pt/termos.

Conforme exposto nos referidos Termos e Condições de Uso, o descarregamento de títulos de acesso restrito requer uma licença válida de autorização devendo o utilizador aceder ao(s) documento(s) a partir de um endereço de IP da instituição detentora da supramencionada licença.

Ao utilizador é apenas permitido o descarregamento para uso pessoal, pelo que o emprego do(s) título(s) descarregado(s) para outro fim, designadamente comercial, carece de autorização do respetivo autor ou editor da obra.

Na medida em que todas as obras da UC Digitalis se encontram protegidas pelo Código do Direito de Autor e Direitos Conexos e demais legislação aplicável, toda a cópia, parcial ou total, deste documento, nos casos em que é legalmente admitida, deverá conter ou fazer-se acompanhar por este aviso.

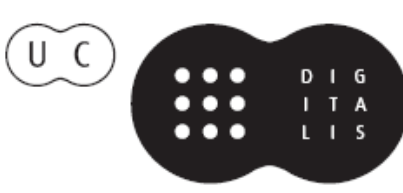


humanitas

\section{Vol. LXIV \\ 2012}

IMPRENSA DA UNIVERSIDADE DE COIMBRA

COIMBRA UNIVERSITY PRESS 
Pese embora o défice informativo do título, nada se retira ao valioso conteúdo da obra, assim eventualmente menos aproveitado pelo leitor. A antologia de textos de Diogo de Paiva de Andrade, da responsabilidade de António Guimarães Pinto, revela o sólido conhecimento da época e das matérias tratadas, a erudição crítica e o mérito científico da tradução a que já nos vem habituando o autor.

Carlota Miranda URbano

DURÁN LÓPEZ, Ma . Ángeles: Los Dioses en Crisis. Actitud de los Sofistas ante la Tendencia Religiosa del Hombre (Madrid, Ediciones Clásicas, 2011) 440 p. ISBN 97884-7882-732-3.

A essência deste livro, cujo título remete para os problemáticos tempos em que vivemos - não necessariamente no domínio do religioso mas ao nível do político, do social e sobretudo do económico - centra-se no secular debate entre mythos e logos. Como nota o seu prefaciador, A. Melero Bellido, que enriquece a edição com um excelente estudo introdutório, trata-se de um livro de tese, bem documentado, tanto no que diz respeito às fontes que utiliza como no suporte bibliográfico crítico em que se sustenta.

De certo modo, o tema remonta aos séculos VI a.C., com Xenófanes, e V a. C., com Hecateu, autores gregos em quem a oposição clássica entre «mito» e «razão» se esboçava já com profunda pertinência. Mas é de facto no século V a. C., com a Sofística, que o debate ganha particular intensidade e relevo, como a A. bem demonstra. O estudo da religião grega ou, como assinala - e bem - Melero Bellido, das «manifestações religiosas gregas» (p. 9) é aqui feito de forma exaustiva, partindo da ideia de que o homem grego, ao contrário do homem moderno, não procurava na religião uma imagem do universo na qual a sua própria vida ganhasse significado e a sua conduta um fundamento ético. $\mathrm{O}$ homem grego vivia e valorizava acima de tudo o ritual, que tendia a invadir todos os quadrantes da sua existência. Tratava-se, por conseguinte, de uma outra forma de viver o religioso. E é esta a ideia que deve presidir ao estudo das «religiões gregas».

A verdade é que nos é praticamente impossível ter uma percepção clara da «religião segundo os Sofistas», dado o estado do material que deles nos chegou: maioritariamente fragmentado. Como tal, os testemunhos disponíveis apenas nos permitem ter acesso a uma visão mutilada da mesma. Ainda 
assim, o corpus associado aos Sofistas, autores frequentemente maltratados por alguma da crítica moderna, permite uma análise do que os seus autores pensavam em traços gerais acerca dos deuses, da religião, do facto religioso em geral, da piedade, da vida post mortem, enfim, do fenómeno religioso enquanto manifestação intrinsecamente humana. Por outro lado, pela sua natureza essencial, os fragmentos que restaram das suas obras e tratados, do seu pensamento em geral, foram, claro, afectados pelos media que permitiram a sua sobrevivência. Designadamente, por Platão e pelo sistema platónico, cuja subjectividade afectou em definitivo o que hoje sabemos acerca dos Sofistas. A começar pela selecção dos passos e fragmentos que neles sobreviveram. Teria sido, por exemplo, do maior interesse conhecer o tratado de Protágoras Acerca dos deuses, em que, muito antes de Cícero, aparentemente se discutia o problema do conhecimento racional dos deuses por parte dos humanos. Um dos aspectos particularmente criticados nestes textos teria sido o carácter antropomórfico dos deuses, o que, na verdade, remontava já aos présocráticos, pelo que, também neste aspecto, os Sofistas se revelam herdeiros de uma tradição anterior.

Sintomático é que entre os Sofistas tenha já desaparecido a necessidade de distinguir religião de mito, o que, aliás, nem sempre é fácil num contexto como o da cultura politeísta grega. Mas «mito» e «rito» parecem ser temas já perfeitamente percepcionados pela Sofística. Outros problemas abordados são os da piedade ou religião pessoal, aqui entendida ou associada ao fenómeno do henoteísmo (uma das problemáticas mais complexas, em termos de abordagem por natureza das fontes disponíveis, no âmbito do estudo das religiões antigas) e o das concepções acerca da vida no Além. Neste último domínio, sentimos falta, claro, de referências à obra, de certo modo pioneira, de M. H. da Rocha Pereira acerca das concepções de felicidade no Além entre os Gregos, desde os Poemas Homéricos até Platão. Já no que diz respeito ao henoteísmo, é particularmente interessante a associação que se faz com o pensamento de Anaximandro e o problema do to theion. Há ainda uma notável discussão em torno das problemáticas do ateísmo e da impiedade entre os Gregos.

Na verdade, há que reconhecer que os Sofistas não foram propriamente originais, na medida em que a sua atitude face à «religião tradicional» dos Gregos se insere numa tradição que remonta pelo menos a Hesíodo e passava por Heraclito, Sólon, Píndaro, Heródoto, Platão ou pelos já mencionados Xenófanes e Hecateu, que visavam já no seu tempo criticar, senão mesmo racionalizar, a mitologia. Ao mesmo tempo, há que levar em 
conta a conjuntura cultural do tempo dos Sofistas, em que correntes paralelas de pensamento mostram que tal atitude em relação ao fenómeno religioso se coaduna com o que encontramos em outros corpora literários, como os escritos hipocráticos, que contribuíram igualmente para uma perspectiva crítica e racional indissociável do processo cultural que caracteriza a Grécia do século $\mathrm{V}$ a. C. Mas há que reconhecer a originalidade quando deparamos com ela e, para $\mathrm{M}^{\mathrm{a}}$. A. Durán, essa característica está no facto de os Sofistas terem abordado estes problemas do ponto de vista teórico. I.e., como problemas em si mesmos e não en passant num qualquer outro contexto.

Também o teatro e os seus autores se revelam fontes fundamentais para o tratamento desta problemática, designadamente Ésquilo e Eurípides, quer pelo «cumprimento da norma» quer pelo «eventual desvio dela» que estes escritores parecem representar. Se Ésquilo parece estar numa ponte construída entre a religiosidade olímpica/homérica tradicional e a religião cívica - numa espécie de compromisso qual sinal dos tempos que então se viviam -, já Eurípides, por exemplo, é outra peça-chave nesta discussão dado que, tal como Protágoras, chegou a ser acusado de ateísmo por alguns dos seus críticos. E, no entanto, estes terão sido dois dos intelectuais gregos que mais se terão preocupado com o problema da natureza dos deuses no seu tempo. Um eventual paradoxo, como nota a A. em conclusão, mas que não deixa de estar totalmente enquadrado no que conhecemos da Cultura Grega.

Em síntese, estamos perante um livro excelente. Um estudo sério, rigoroso, exaustivo que deverá servir de obra de referência para todos os que se dedicam ao estudo da religiosidade dos Gregos. Eventualmente, a edição poderia ser melhorada com a inclusão de índices de passos citados e de nomes próprios e temas. Há que não esquecer que estes são instrumentos de trabalho básicos, hoje fundamentais em qualquer edição científica.

NUNO S. RODRIGUES

EURÍPIDES, Tragédias II. Tradução do grego, Introdução e notas de Frederico Lourenço, José Ribeiro Ferreira, Maria do Céu Fialho, José Luís Coelho e Carlos Ferreira Santos. Lisboa, INCM, 2010.

$\mathrm{O} 2^{\circ}$ volume das Tragédias de Eurípides, que integra o projecto editorial da colecção Biblioteca de Autores Clássicos da Imprensa Nacional Casa da Moeda, coordenado por Maria de Fátima Sousa e Silva (Universidade 